\title{
GOOD, BAD AND DARK BITCOIN: A Systematic Literature Review
}

\author{
Untung Rahardja', Qurotul Aini' ${ }^{2}$, Eka Purnama Harahap ${ }^{3}$, Raihan $^{4}$ \\ University of Raharja,Indonesia ${ }^{1,2,3,4}$ \\ Jl. Jenderal Sudirman No.40, RT.002/RW.006, Cikokol, Kec. Tangerang, Kota Tangerang, \\ Banten $15117^{1,2,3,4}$ \\ e-mail: untung@raharia.info ${ }^{1}$, aini@raharia.info ${ }^{2}$, ekapurnamaharahap@raharia.info ${ }^{3}$, \\ raihan.raihan@raharja.info ${ }^{4}$
}

Rahardja, U., Aini, Q., Purnama Harahap, E. ., \& Raihan, R. (2021). GOOD, BAD AND

DARK BITCOIN: A Systematic Literature Review . Aptisi Transactions on

Technopreneurship (ATT), 3(2).

DOI: https://doi.org/10.34306/att.v3i2.175

\begin{abstract}
Crypto currency investments have been in demand since the popularity of bitcoin. Crypto currency (cryptocurrency) is a currency based on cryptography or digital currency. The birth of bitcoin as one of the important foundations in the formation of the reputation of the crypto currency. Investing in crypto currencies is considered to provide more security and large profits for investors, with a cryptographic system the crypto currency is difficult to hack and fake. This cryptocurrency is also a digital key with encryption capabilities as security and validity, as well as real value that can be exchanged as an option. The most popular type of virtual currency is known as Bitcoin, and its popularity and strength continue to increase. At first glance, Bitcoin is very confusing. But here are ten facts that can be explained in simple terms, exactly what that little coin is and what happens.
\end{abstract}

Keywords: Blockchain, Bitcoin, CryptoCurrency.

\section{Introduction}

The term 'bitcoin' has appeared in the news and continues to attract people's attention. Today, Bitcoin is one of the most popular topics in search engines and social networks, and continues to increase. The rising price of bitcoin has attracted the attention of many people about this cryptocurrency [1]. People learn more to understand the process of investing in this encrypted network to make a profit. Bitcoin is generally called a distributed digital call and uses a password convention to produce units of digital currency [2].

\section{Research Method}

A Systematic Literature Review is defined as a method for gathering, identifying and interpreting research to answer certain research questions. We have conducted A Systematic Literature Review relying on materials collected through library studies in the form of books, journals, theses, theses, and the internet. The results of the literature study are then used to analyze problems that arise in the future [3].

\subsection{Literature Review}

\section{What Is Cryptocurrency Like?}

As the name suggests, cryptocurrency is a coin generated by computer code and there is no central bank or issuer like the Indian Reserve Bank (RBI). In addition, 
cryptocurrency is generated by miners on the network as a solution to complex problems and mathematical problems. In short, Bitcoin is similar to virtual cash stored in online wallets such as Paytm, Ola Money, Freecharge, etc. You can use this virtual currency to buy products or services over the Internet. Bitcoin uses decentralized technology to store payments and money does not require a username [4].

\section{Who Created Bitcoin?}

The Bitcoin network or currency was introduced in 2009 by an unknown person named Satoshi Nakamoto. Anonymous inventor launched a white paper in 2009 with this cryptocurrency concept in 2008. He launched it as an open source software [5]. Use point-to-point technology (electronic version of cash) (point-to-point) to transfer payments online directly to other parties without going through financial institutions. Manage transactions without a central trade institution or financial institution. The problem of Bitcoin (BTC) is known as mine and is carried out together in a network [6].

\section{Unique Bitcoin Characteristics:}

- Decentralized

- There is no bank

- There is no government

- There is no capital limit

- Account Cannot Be Blocked

- Acting as a currency

- Secure transaction and storage of all types of data

- The popularity of Bitcoin is anonymity and confidentiality.

- Aside from being an option for making payments anonymously, it also attracts money launderers and tax evaders.

You can convert bitcoin into cash using a bitcoin exchange which makes it possible to sell Bitcoin at a reasonable price, for local currencies (such as dollars, euros etc.). You can exchange Bitcoin for US dollars on the website and ask them to transfer to your bank account [6].

- Coinbase - Coinbase - Buy / Sell digital currencies.

- Bitstamp - https://www.bitstamp.net.

Bitcoin can be sold online in cash. Services such as Bit Quick and Local Bitcoin can accept cash payments online from Bitcoin. Selling Bitcoin is no different from buying Bitcoin. Bitcoin is the first step in finding a business partner that pays to exchange or desired payment. From there, you can complete a transaction to sell Bitcoin [6].

\section{Findings}

Based on the research that you've done, you can write your result in this section, there will be 2 sub-bab which are Problem, and Research Implementation. therefore if you have more results you can add more sub-bab on the section below.

\subsection{Problem}

\section{A. RQ1 What's Interesting About bitcoin?}

- Ease of use: You need a device that supports the internet (cell phone / laptop / desktop / Wearable) to access the wallet. Using your wallet, you can use crypto currency.

- Safe: Crypto currency is digital and cannot be falsified or reversed arbitrarily by the sender, as is the case with credit card backs.

- 3rd party deletions that allow immediate settlement: Bitcoin contracts can be arranged and executed to exclude or enter third party permits, compare additional information or be carried out at a future date or time for a fraction of the cost and time needed to complete a standard asset transaction [7].

- Decentralization: You know that crypto currencies do not have central control 
power, networks are spread to all users, each computer mining node is a member of this framework. This ensures that the central authority does not have the power to dictate laws for the owners of crypto currencies [8].

- Transaction Fees: Usually there are no transaction fees for exchange of crypto currencies, because the network compensates miners.

- Secure Identity: When you give your merchant a credit card, you give him access to your entire credit limit, even if you have a small purchase. Credit cards work on a "pull" basis, where the store starts the bill and takes out of your wallet the allocated balance. Crypto currency uses a push mechanism that allows crypto currency holders to send to merchants or recipients exactly what the user wants without further details [9].

- Universal Availability: You know how to open a basic bank account, they ask you for many documents if there are errors in the documents, then they refuse to open an account, and it's rather difficult to access funds in different geographical areas [10].

- Universal Acceptance: Because crypto is not limited by exchange rates, interest rates, transaction fees or other fees from any country, it can be used globally without problems.

- Transparency: Every transaction on the crypto currency is registered on the underlying Blockchain. Someone can see public data specified by the user.

- Anonymity: In crypto currency, regardless of name, address, or other details, you can create an unlimited number of wallets.

\section{B. RQ2 What's Bad About Bitcoin?}

- Lack of knowledge: Most users don't know best practices or how to use cryptocurrency and are therefore vulnerable to hackers. Crypto currency technology is rather complicated and therefore people need to gain knowledge because before using and / or investing [11].

- Volatility: Crypto currencies are very volatile \& this is one of the reasons for slower adoption of cryptocurrency. Little-known cryptos may be driven by scammers and users can eventually lose money in an unstable scenario [12].

- Exchange Stability: Exchanges that facilitate transactions do not have a sustainable business model so most of them do not operate after 2-3 years. Let's go through the classic case of Mt. Gox exchange. Mt. Gox is a bitcoin exchange based in Shibuya, Tokyo, Japan. Launched in July 2010, in 2013 and entering 2014 , it handles more than $70 \%$ of all bitcoin transactions worldwide, as the largest bitcoin intermediary and the world's leading bitcoin exchange. In February 2014, Mt. Gox suspended trade, closed its website and exchange services, and filed for bankruptcy protection from creditors. In April 2014, the company began the liquidation process [13].

- Government Regulations: Not many governments get clear regulations. Sometimes, this impacts cross-border transactions.

- Transaction Speed: Traditional CryptoCurrency Network Architecture limits the speed and thus the number of transactions completed per minute. This is one obstacle to adoption. Crypto Currency Networks will need time to reach the speed of transactions such as cellular recharging or the current digital payment network, which is the speed of completion of UPI transactions in India [14].

- Application / Restricted Use Case: At present, due to slower adoption rates, one cannot use crypto everywhere for all types of transactions. Most major retailers and service providers have not universally accepted cryptocurrency. So, users must save money in multi-currency format, e.g. Fiat money as well as some crypto currencies [15].

- Storage: If you store cryptocurrency on your cell phone or computer, store and secure passwords better and don't forget. Losing a password means you can't get it 
back.

\section{RQ3 What's Bad About Bitcoin?}

- Criminal favorite currency: Most ransomware attacks demand a ransom in crypto. There are many scenarios where cryptocurrency can serve a number of very negative purposes. i.e. Money Laundering, Cyber Fraud, Fraud / Fraudulent down payment fees, Volatility can cause huge losses for large investors, finance some clandestine activities (terrorist left wing organization / Radical / blood diamond trading / unethical trading) and last but not least of ease of use / anonymity help the Dark web [16]. Below is one of the best documentaries that you can find on Bitcoin [17]. On August 1, 2015, Mark Karpeles came out of his house in Tokyo under police escort. A few hours later, Mark was charged and jailed for faking computer data and embezzlement in connection with the loss of 850,000 Bitcoin, equivalent to half a million dollars [11].

- ICO Trust: ICO, or initial coin offering, is used by people who want to start their own crypto currency, aka altcoin. This is an attempt to raise money through crowdfunding, such as the Kickstarter campaign, in return for new coins [18]. These coins are launched by individuals or groups of individuals by creating attractive names from crypto coins that are supported by aggressive marketing. But much of this crowdfunding effort is fraudulent, scammers can get away with all the money with little or no accountability [19]. There are not many legal guidelines so that such ICO fraud can potentially occur with little or no legal problems. This is due to the fact that the money back is not guaranteed. As with any investment, it can be expected that all your money can be lost, so fraudsters only claim ICOs fail and run away with your money. Satis Group has identified that $78 \%$ of ICO is fraud. You can access the article here [20].

\section{Conclusion}

Money has played an important role in human society since at least $9000 \mathrm{BC}$, with a currency that continues to grow to meet the needs of every changing society. Today, the explosion of personal computing and cellular technology continues to drive the evolution of money, introducing new opportunities and challenges. On the other hand, Blockchain has challenged every industry domain by upsetting trust. What does the future bank look like? Will cash continue to support our society? Will Blockchain technology be overhyped or revolutionary in the next two years? Time will be proven. The continuing global threat caused by COVID-19 will ultimately trigger the use of digitalization and result in higher adoption of crypto currencies. It will also provide citizens to reduce the use of conventional money and the opportunity to stay safe from coronavirus.

\section{References}

[1] K. M. Moriarty, Transforming Information Security: Optimizing Five Concurrent Trends to Reduce Resource Drain. Emerald Group Publishing, 2020.

[2] U. Rahardja, Q. Aini, H. D. Ariessanti, and A. Khoirunisa, "Pengaruh Gamifikasi pada iDu (iLearning Education) dalam Meningkatkan Motivasi Belajar Mahasiswa," NJCA (Nusantara J. Comput. Its Appl., vol. 3, no. 2, pp. 120-124, 2018.

[3] N. Siegfried, T. Rosenthal, and A. Benlian, "Blockchain and the Industrial Internet of Things: A requirement taxonomy and systematic fit analysis," J. Enterp. Inf. Manag., 2020.

[4] U. Rahardja, I. Handayani, and A. A. Ningrum, "Pemanfaatan Sistem iMe Berbasis WordPress sebagai Official Site RCEP pada Perguruan Tinggi," Creat. Inf. Technol. J., vol. 4, no. 3, pp. 207-219, 2018.

[5] S. Ayvaz and S. C. Cetin, "Witness of Things: Blockchain-based distributed decision record-keeping system for autonomous vehicles," Int. J. Intell. Unmanned Syst., 2019.

[6] Q. Aini, Y. I. Graha, and S. R. Zuliana, "Penerapan Absensi QRCode Mahasiswa Bimbingan Belajar pada Website berbasis YII Framework," Sisfotenika, vol. 7, no. 2, pp. 207-218, 2017. 
[7] A. B. Turner, S. McCombie, and A. J. Uhlmann, "A target-centric intelligence approach to WannaCry 2.0," J. Money Laund. Control, 2019.

[8] J. Lin, Z. Shen, C. Miao, and S. Liu, "Using blockchain to build trusted LoRaWAN sharing server," Int. J. Crowd Sci., 2017.

[9] D. Sinha and S. R. Chowdhury, "Blockchain-based smart contract for international business-a framework," J. Glob. Oper. Strateg. Sourc., 2021.

[10] R. L. Rana, C. Tricase, and L. De Cesare, "Blockchain technology for a sustainable agri-food supply chain," Br. Food J., 2021.

[11] P. R. Sousa, J. S. Resende, R. Martins, and L. Antunes, "The case for blockchain in loT identity management," J. Enterp. Inf. Manag., 2020.

[12] N. Kant, "Blockchain: a strategic resource to attain and sustain competitive advantage," Int. J. Innov. Sci., 2021.

[13] S.-C. Oh, M.-S. Kim, Y. Park, G.-T. Roh, and C.-W. Lee, "Implementation of blockchain-based energy trading system," Asia Pacific J. Innov. Entrep., 2017.

[14] R. P. George, B. L. Peterson, O. Yaros, D. L. Beam, J. M. Dibbell, and R. C. Moore, "Blockchain for business," J. Invest. Compliance, 2019.

[15] Q. Aini, I. Handayani, and C. A. Seto, "Content Management System Zpreneur in Support of Entrepreneurship Ilearning at Perguruan Tinggi Raharja," Creat. Commun. Innov. Technol. J., vol. 8, no. 3, pp. 233-245, 2015.

[16] U. Rahardja, Q. Aini, and D. Sartika, "Build A Business To Customer Online Store Using Airzone Content Management System," CCIT J., vol. 8, no. 2, pp. 112-122, 2015.

[17] U. Rahardja, Q. Aini, and A. Khoirunisa, "The Effect of Rinfogroups as a Discussion Media in Student Learning Motivation," Aptisi Trans. Manag., vol. 2, no. 1, pp. 79-88, 2018.

[18] R. Untung, I. Handayani, and B. A. Pahad, "Pemanfaatan Rinfoform Sebagai Media Update Artikel Pada iRan," J. CSRID, vol. 8, no. 3.

[19] X. Xue, J. Dou, and Y. Shang, "Blockchain-driven supply chain decentralized operations-information sharing perspective," Bus. Process Manag. J., 2020.

[20] P. Xie, Q. Chen, P. Qu, J. Fan, and Z. Tang, "Research on financial platform of railway freight supply chain based on blockchain," Smart Resilient Transp., 2020. 